\title{
ORTHODOXY AND METHODISM AS VIEWED BY RUSSIAN TEENAGERS
}

\section{Szergej Glotov}

$\mathrm{PhD}$, Faculty of ecology, management and law, Non-state Educational Establishment of Higher Professional Education " IIUEPS Academy ", Penza branch, Russia

E-mail: zamumr.penza@mnepu.ru

Keywords: Orthodoxy; Protestantism; values; traditions; teenagers

Annotation: the article considers the comparison of values of Orthodoxy and Protestantism as viewed by Russian teenagers.

A wide-spread way of international cooperation today is youth interchange, when teenagers from one country come to a different country to stay for some time in their equals in age' families. And then they themselves host foreign guests in their own country and family. One of organizations carrying out such projects in Penza is Penza Branch of Russian Pease Foundation. The author of this report is a youth-orientated programs coordinator in this organization and in particular a tutor of Russian teenagers' group who made a "peace voyage" to the State of Mississipi, USA. The sponsor of the visit and the host side was the Methodist Community of the state as it is the church which carries out such projects as well as many other kinds of educational work with young people in the USA.

The aim of the present publication is not a speculative and concept-based apprehension of the two Christianity branches, but a retrospective analysis of Russian teenagers' views on Orthodoxy and Protestantism. Following the results of a two weeks visit the author of the report who is a professional educator interviewed the 26 young participants of the visit, held individual conversations and roundtable discussions with them. In the author's view religious studies and education science have a lot of contact points, so the professional religious scholars can use the empirical data (which are a short record of the teenagers' opinions) in their work and give theoretic comprehension to them.

It is not the author's aim to draw some far-reaching conclusions; he confines himself to the summary of main opinions heard. However, in the author's point of view much speaks for itself most eloquently. Besides one should take into particular consideration that 14-, 18-year old "peace voyage" participants grew up in an atheistic-orthodox country and were acquainted with Methodism for two weeks only.

So the opinions of "peace voyage" participants:

Table 1.

\begin{tabular}{|c|l|l|}
\hline No & \multicolumn{1}{|c|}{ Orthodoxy } & \multicolumn{1}{|c|}{ Methodism } \\
\hline 1 & $\begin{array}{l}\text { Church-government completely copies } \\
\text { the political system built upon the } \\
\text { principle of a pyramid; all decisions are } \\
\text { made in an authoritarian way; members of } \\
\text { clergy are appointed for life }\end{array}$ & $\begin{array}{l}\text { Church-government is democratic and } \\
\text { open for everyone; there are no appointed } \\
\text { for life members of clergy; pastors are } \\
\text { chosen by the church community from } \\
\text { time to time; decision-making is } \\
\text { collective }\end{array}$ \\
\hline
\end{tabular}




\begin{tabular}{|c|c|c|}
\hline 2 & $\begin{array}{l}\text { Close association with politics } \\
\text { (participation in elections, political } \\
\text { actions, even blessing of troops and } \\
\text { military hardware for military operations) }\end{array}$ & $\begin{array}{l}\text { No close association with politics; no } \\
\text { close contacts with local officials; } \\
\text { clergymen do not participate in political } \\
\text { actions }\end{array}$ \\
\hline 3 & $\begin{array}{l}\text { Implacability to other confessions; wish } \\
\text { of sole spiritual domination (refusal to } \\
\text { meet with the Pope, fighting of religious } \\
\text { sects which is struggle with Protestantism } \\
\text { in actual fact) }\end{array}$ & $\begin{array}{l}\text { Peaceful coexistence of different } \\
\text { confessions (Orthodox, Baptist, } \\
\text { Methodist churches and religious centres } \\
\text { are located near each other); no } \\
\text { implacability, no desire to exalt } \\
\text { Methodism }\end{array}$ \\
\hline 4 & $\begin{array}{l}\text { Church finances are out of any control. } \\
\text { The origin of substantial sums of money } \\
\text { for building and reconstruction of temples } \\
\text { is unknown. It is impossible to do it for } \\
\text { the money of half-pauper parishioners. In } \\
\text { practice the state sponsors the church, } \\
\text { which is legally separated from the state }\end{array}$ & $\begin{array}{l}\text { It is not the state but the parishioners } \\
\text { sponsor the church. This is possible } \\
\text { because their salaries afford it. } \\
\text { Transparence of finances. There are } \\
\text { memorial tablets everywhere with the } \\
\text { names of persons who made gifts to the } \\
\text { church }\end{array}$ \\
\hline 5 & $\begin{array}{l}\text { Obscure ceremonies and rituals which } \\
\text { became a thing of the past are preserved } \\
\text { under the cover of "traditions". } \\
\text { Unwillingness and inability to change } \\
\text { anything, but on the contrary pride for it }\end{array}$ & $\begin{array}{l}\text { Willingness to any changes and } \\
\text { innovations according to people's } \\
\text { demands and to the spirit of the times: } \\
\text { church service is easy to understand, } \\
\text { Hymn singing is accompanied by pop } \\
\text { groups, organization of Methodist } \\
\text { summer camps for scouts, discos, } \\
\text { membership clubs, gyms, etc. affiliated to } \\
\text { the church }\end{array}$ \\
\hline 6 & $\begin{array}{l}\text { Accentuated hierarchical pattern between } \\
\text { the members of clergy (in clothing, in } \\
\text { right to enter the chancel, in kissing the } \\
\text { hand, the cross, parishioners are obliged } \\
\text { to stand while attending the church } \\
\text { service, women are to cover their heads in } \\
\text { church, etc.) }\end{array}$ & $\begin{array}{l}\text { No accentuated hierarchical pattern. } \\
\text { Communication style agrees with } \\
\text { contemporary general civil etiquette. } \\
\text { Pastor is one of the parishioners. No } \\
\text { ostentatious grandeur and selectness }\end{array}$ \\
\hline 7 & $\begin{array}{l}\text { A parishioner is a servant of God. This is } \\
\text { emphasized even by church architecture } \\
\text { (for example a typical Russian village } \\
\text { represents shabby hovels and a temple } \\
\text { which dominates over them like } \\
\text { Gulliver's dwelling over Liliputians' } \\
\text { houses), pompous interiors in the House } \\
\text { of God, strict order of behaviour there }\end{array}$ & $\begin{array}{l}\text { A parishioner is a God's coworker, } \\
\text { created in the image and likeness of God. } \\
\text { Churches differ very little from the } \\
\text { buildings surrounding them, not stressing } \\
\text { their superiority. The interiors are modest, } \\
\text { there are no pompous decorations. } \\
\text { Everything is made for the convenience of } \\
\text { parishioners (armchairs in assembly halls, } \\
\text { recreation rooms, refectories, free foods } \\
\text { and drinks, gyms, nurseries, billiard } \\
\text { rooms, etc. }\end{array}$ \\
\hline 8 & $\begin{array}{l}\text { Inclination to religionism: tremendous } \\
\text { buildings, abundance of icons and } \\
\text { decorations, chimes, needless to God as to } \\
\text { an Ens Supremum. In sober fact all this is } \\
\text { meant to fetch out the authority of church }\end{array}$ & $\begin{array}{l}\text { Religionism is pared down to the } \\
\text { minimum: no tremendous buildings, } \\
\text { icons, decorations, chimes, as God lives in } \\
\text { human hearts and in their good deeds }\end{array}$ \\
\hline
\end{tabular}




\begin{tabular}{|c|c|c|}
\hline 9 & $\begin{array}{l}\text { Only a specially appointed by the church } \\
\text { person can be a clergyman }\end{array}$ & $\begin{array}{l}\text { Any charismatic community leader can } \\
\text { become a clergyman }\end{array}$ \\
\hline 10 & $\begin{array}{l}\text { Image of Christ on the road to the Calvary } \\
\text { dominates: suffering is emphasized, } \\
\text { gloomy, strict faces, feeling of guilt, } \\
\text { masochism }\end{array}$ & $\begin{array}{l}\text { Image of Christ speaking of Kingdom of } \\
\text { Heaven on the Earth dominates: } \\
\text { happiness to be all together, amiable } \\
\text { faces, feeling of personal value and } \\
\text { significance }\end{array}$ \\
\hline 11 & $\begin{array}{l}\text { A clergyman is a person "not of this } \\
\text { world", with a mystic aureole, removed } \\
\text { from all the rest for a certain distance }\end{array}$ & $\begin{array}{l}\text { A clergyman is the best of parishioners, } \\
\text { the one they trust more than anyone }\end{array}$ \\
\hline 12 & $\begin{array}{l}\text { There are voluntary half-prisons which } \\
\text { are called monasteries. They pursue a } \\
\text { counterintuitive aim - to pray for people } \\
\text { while being isolated from them }\end{array}$ & $\begin{array}{l}\text { There are no monasteries. One should do } \\
\text { good directly (direct-action principle). It } \\
\text { is unworthily to isolate from people }\end{array}$ \\
\hline 13 & $\begin{array}{l}\text { Lop-sided church organization: only } \\
\text { religion in church }\end{array}$ & $\begin{array}{l}\text { Multitask functionality of the church (in } \\
\text { fact it is a centre of Christian life): } \\
\text { educational programs, membership clubs } \\
\text { for all ages, sports competitions, discos, } \\
\text { celebrations, contests, Bible studies, pop } \\
\text { groups, nurseries, etc. }\end{array}$ \\
\hline 14 & $\begin{array}{l}\text { A clergyman is only a clergyman. } \\
\text { Sometimes he comes to school and } \\
\text { explains religious formulas in a way } \\
\text { which is difficult to understand }\end{array}$ & $\begin{array}{l}\text { Pastor is not only a clergyman, but is also } \\
\text { a facilitator of community leisure, its } \\
\text { leader, educational psychologist, often a } \\
\text { sportsman (who arranges events, plays } \\
\text { with children) }\end{array}$ \\
\hline 15 & $\begin{array}{l}\text { A boy can be ousted from the temple if he } \\
\text { enters it in shorts, and a girl - if she does } \\
\text { not cover her head with a kerchief. It } \\
\text { happened to the teenagers from the } \\
\text { interviewed group in Christ the Saviour } \\
\text { Cathedral in Moscow }\end{array}$ & $\begin{array}{l}\text { One can wear any clothing (except } \\
\text { immodest), as this is not the main thing. A } \\
\text { pastor wearing jeans once was preaching } \\
\text { from the chancel }\end{array}$ \\
\hline 16 & $\begin{array}{l}\text { The clergymen chant in a complicated } \\
\text { way not easy to understand for an } \\
\text { unprepared person }\end{array}$ & $\begin{array}{l}\text { The pastor speaks clearly in a common } \\
\text { modern language. It seems as if you listen } \\
\text { to a teacher who explains something in a } \\
\text { very interesting way. There are elements } \\
\text { of dramatic performance in speeches }\end{array}$ \\
\hline 17 & $\begin{array}{l}\text { Only clergymen have the right to } \\
\text { comment on the Bible }\end{array}$ & $\begin{array}{l}\text { During the Bible study lessons all } \\
\text { students are allowed to comment on it as } \\
\text { they understand it }\end{array}$ \\
\hline 18 & $\begin{array}{l}\text { When christened children are immersed } \\
\text { into a laver: children often cry and can } \\
\text { catch a cold }\end{array}$ & $\begin{array}{l}\text { When christening pastor slightly moistens } \\
\text { child's head. The child is quiet. }\end{array}$ \\
\hline 19 & $\begin{array}{l}\text { Woman's rights in church differ from } \\
\text { those of man and, all the more so from the } \\
\text { rights of clergymen }\end{array}$ & $\begin{array}{l}\text { Woman's rights in church do not differ } \\
\text { from those of man. She has the right to } \\
\text { enter the chancel which represents a } \\
\text { beautiful stage, she can play the piano } \\
\text { there, she can speak, address to everybody }\end{array}$ \\
\hline
\end{tabular}




\begin{tabular}{|c|l|l|}
\hline 20 & $\begin{array}{l}\text { When the church service is finished } \\
\text { everybody goes away without any } \\
\text { intercourse, young people mostly not } \\
\text { attend churches. Church is not the place } \\
\text { for young people to meet }\end{array}$ & $\begin{array}{l}\text { Everybody knows each other in the } \\
\text { community, visit each other, meet in } \\
\text { church, young people get acquainted, get } \\
\text { married. After the church service nobody } \\
\text { leaves, and all } \\
\text { intercommunicate, talk about their } \\
\text { impressions }\end{array}$ \\
\hline 21 & $\begin{array}{l}\text { To take communion wine and prosphora } \\
\text { (Holy bread) are used }\end{array}$ & $\begin{array}{l}\text { To take communion juice of red colour } \\
\text { and any bread are used }\end{array}$ \\
\hline 22 & $\begin{array}{l}\text { Those wishing to kneel down have to do } \\
\text { it on cold dirty floor. It is especially } \\
\text { difficult for elderly people. The } \\
\text { parishioners have to stand during the } \\
\text { church service, which is not convenient } \\
\text { for people }\end{array}$ & $\begin{array}{l}\text { Those wishing to kneel down do it on a } \\
\text { special velvet pillow along the chancel. } \\
\text { To stand up they use a special parapet. } \\
\text { The parishioners sit during the church } \\
\text { service, which is convenient for people }\end{array}$ \\
\hline 23 & $\begin{array}{l}\text { Orthodoxy is meant for a country where } \\
\text { people suffer much, as it preaches } \\
\text { patience to suffering. If there is less } \\
\text { suffering orthodoxy will be non- } \\
\text { demanded }\end{array}$ & $\begin{array}{l}\text { Methodism is typical for successful } \\
\text { countries. It preaches not to stand } \\
\text { sufferings, but to try to reduce them }\end{array}$ \\
\hline 24 & $\begin{array}{l}\text { Orthodox countries are poor, } \\
\text { relationships between people are rude: } \\
\text { Russia, Belarus, Bulgaria }\end{array}$ & $\begin{array}{l}\text { Catholic countries live better: Poland, } \\
\text { Baltic States, Italy, Spain, France, etc. } \\
\text { Methodism is the religion of the richest } \\
\text { countries who are proud of their liberty: } \\
\text { the USA, Australia, Great Britain }\end{array}$ \\
\hline
\end{tabular}

Though the opinions stated above sound very categorical one should not judge them in the same way: either strictly negatively or only positively.

The upside is that the younger generation rejects many traditionally conservative forms of organization in social, political life and the world of spirit life in Russia: the principle of unity of command in peacetime, dogmatism, ideology, gerontocracy, a cult of everlasting "holy" poverty and self-denial. Reprobation of these forms might contain the dawning of some democratic and humanitarian values which are new for Russia and are born by West-European and American Protestantism. It should be noted that the youngsters' opinions have much in common with the ideas of Max Weber [1] who made a detailed survey of Protestant ethics which brought forth the contemporary successful West and the USA. While staying in the USA the teenagers felt and acclaimed most enthusiastically Protestant main values: activity, discipline, responsibility, rejection of deception and coercion, willingness to changes and to development. A Christian-Protestant-Methodist is distinctive not for his readiness for selfsacrifice and heroic acts or foolhardiness for the sake of yet another sacred cow. He is distinctive for his felicity to everyday labour, which should be rewarded, for his individual liberty and responsibility, for self-actualization, for conjunction of spirit and matter, moderation and prosperity. A person has an opportunity to cultivate his abilities here and now, but not in the Kingdom of Heaven or in some ambiguous future. He is free to use his liberty at his sole discretion and to live not in spite of human nature but to actualize its best features.

The downside in the author's opinion is the traditional Russian lack of sense of proportion, running to extremes in estimations and appraisals: from "aggressive dislike" passing into hatred to "adoration" rushing into imitation and deindividuation. Such "aggressive dislike" and 
"adoration" slide into each other according to the law of the unity and struggle of opposites. The source of danger here is that the essential modernization might be perceived as totalitarian westernization which fails to consider proper specificity, customs and mentality. It is typical that in the rage of breaking those who break do not notice such things. In his poem "Russia" Maximilian Voloshin [2] wrote about it as follows:

In our inward soul we're scornful of the West,

But in the search of gods

We thieve from there away

Its Hegels and its Marxes...

And clamber them upon pagan Olympus

In order to incense to them styrax and brimstone

Meanwhile severing heads of our own gods.

And just a year on -

A peregrine blockhead is seen

Dragged on the horsetail

To be drowned in the river...

(transl. by Irene Shelyakina)

Consequently there is a possibility that everything starts again from the clean slate, passing the stages of birth, death and rebirth. However it is also a typical mistake to try to isolate from deep influence of Protestantism and not to change anything.

The way out is in the unity of varieties, in the combination of traditions and innovations, in «consistent development» and «coevolution» [3], in preservation of our individual specific features and active adoption of the best achievements of Protestantism, such as church educational work methods.

\section{References}

1. Макс Вебер. Протестантская этика и дух капитализма. - М.: Ист-Вью, 2002. - 352 c.

2. Волошин М.А. Собрание сочинений в 8-ми томах. Том 2. Стихотворения и поэмы 1891-1931, Изд-во «Эллис Лак», 2003.

3. Моисеев Н.Н. Слово о научно-технической революции / - 2-е изд., доп. - М.: Мол. гвардия, 1985. - 238 с. 